\title{
NONDIPHTHERIAL CORYNEBACTERIUM SPECIES ISOLATED FROM CLINICAL SPECIMENS OF PATIENTS IN A UNIVERSITY HOSPITAL, RIO DE JANEIRO, BRAZIL
}

\author{
Thereza Cristina Ferreira Camello ${ }^{1}$; Ana Luiza Mattos-Guaraldi²*; Luiz Carlos Duarte Formiga ${ }^{3}$; \\ Elizabeth Andrade Marques ${ }^{4}$
}

${ }^{1}$ Laboratório de Bacteriologia, Hospital Universitário Pedro Ernesto, Universidade do Estado do Rio de Janeiro, Rio de Janeiro, RJ, Brasil; ${ }^{2}$ Laboratório de Difteria e Corineformes de Importância Médica, Disciplina de Microbiologia e Imunologia, Faculdade de Ciências Médicas, Universidade do Estado do Rio de Janeiro, Rio de Janeiro, RJ, Brasil; ${ }^{3}$ Departamento de Microbiologia

Médica do Instituto de Microbiologia, Universidade Federal do Rio de Janeiro, Rio de Janeiro, RJ, Brasil; ${ }^{4}$ Disciplina de Microbiologia e Imunologia, Faculdade de Ciências Médicas, Laboratório de Bacteriologia do Hospital Universitário Pedro Ernesto, Universidade do Estado do Rio de Janeiro, Rio de Janeiro, RJ, Brasil.

Submitted: March 14, 2001; Returned to authors for corrections: July 25, 2001; Approved: December 05, 2002

\begin{abstract}
Over a five-year period, 163 strains of Corynebacterium sp. were recovered from different clinical specimens of patients from a Brazilian University hospital. Genitourinary tract and intravenous sites specimens were the most frequent sources of corynebacteria (46.62\%). Corynebacterium amycolatum (29.55\%), Corynebacterium minutissimum (20.45\%) and Corynebacterium pseudodiphtheriticum (13.63\%) were the predominant species found in genitourinary tract. C. minutissimum (24.14\%) and Corynebacterium propinquum (17.24\%) in surgical and/or other skin wounds and abscesses; Corynebacterium xerosis (25\%), C. amycolatum $(21.87 \%)$ and $C$. pseudodiphtheriticum (18.75\%) in intravenous sites; C. pseudodiphtheriticum (33.33\%) and C. propinquum $(33.33 \%)$ in lower respiratory tract. Microorganisms were all susceptible to vancomycin and most of the species was predominantly resistant to $\beta$-lactams. Antimicrobial susceptibility patterns of corynebacteria were not predictable. Multiple antibiotic resistance observed in C. jeikeium was also found among C. xerosis, C. minutissimum, C. afermentans, C. propinquum, C. amycolatum and C. pseudodiphtheriticum strains. Data suggest awareness of clinicians and microbiologists to nosocomial infections especially due to antimicrobial multiresistant strains of Corynebacterium sp.
\end{abstract}

Key words: Corynebacterium sp, nondiphtherial corynebacteria, nosocomial infections, multiresistance

\section{INTRODUCTION}

Corynebacterium species, other than Corynebacterium diphtheriae, have been reported with an increasing frequency $(60 \%)$ as nosocomial pathogens $(3,13)$. The increase in the number of reports concerning Corynebacterium infections may be due to better knowledge of taxonomy of these organisms, better identification schemes, and/or growing population of immunocompromised patients $(10,11,12,19,23)$.
Several species, such as Corynebacterium xerosis, Corynebacterium amycolatum, Corynebacterium striatum, Corynebacterium minutissimum, Corynebacterium pseudodiphtheriticum, Corynebacterium matruchotii, "Corynebacterium aquaticum", Corynebacterium genitalium, and Corynebacterium pseudogenitalium, have been related to human infections. Corynebacterium jeikeium and Corynebacterium urealyticum are well-established human pathogens exhibiting resistance to several antibiotics $(10,19)$.

\footnotetext{
* Corresponding author. Mailing address: Laboratório de Difteria e Corineformes de Importância Médica, Disciplina de Microbiologia e Imunologia. Faculdade de Ciências Médicas, Universidade do Estado do Rio de Janeiro. Av. 28 de Setembro, 87 - Fundos, $3^{\circ}$ andar, Vila Isabel. 20 551-030, Rio de Janeiro, Brasil. Telephone: (+5521) 2587- 6380. Fax: (+5521) 2587- 6476.
} 
The Corynebacterium pseudotuberculosis, Corynebacterium kutscheri, and Corynebacterium renale group has been occasionally found in human specimens $(3,10,11,13,19)$. During the last decade, new species isolated from humans have been described: Corynebacterium auris, Corynebacterium argentoratense, Corynebacterium durum, Corynebacterium imitans, Corynebacterium mucifaciens, Corynebacterium lipophiloflavum, Corynebacterium coyleae, Corynebacterium riegelii (10), Corynebacterium confusum, Corynebacterium thomssenii $(10,12)$, Corynebacterium falsenii $(10,20)$, Corynebacterium kroppenstedtii and Corynebacterium sundsvallense $(2,12)$.

Microbiology laboratories focused their isolation and identification capabilities to recognize established pathogens such as Listeria, Erysipelothrix, Actinomyces, C. diphtheriae and, later, C. jeikeium. Since the introduction of indwelling intravenous (i.v.) catheters and their increased use, laboratories have experienced an increase in blood and catheter-related isolations of Gram-positive rods, often in quantities or repetitive isolations suggestive of potential clinical relevance. Emerging antimicrobial resistance in various species has created an additional need for accurate identification of corynebacteria organisms at the species level and continuous surveillance of their antimicrobial resistance patterns $(19,23)$. The identification of aerobically growing Grampositive rods in a routine diagnostic laboratory presents several problems. Some laboratories still consider most of these bacteria as contaminants, others are content with characterizing even strains with suggestive clinical significance as "diphtheroids", again others use miniaturized identification schemes, which, however, may have a limited scope (10).

In Brazil, the identification of nondiphtherial corynebacteria species has been a subject of concern since $1974(1,4,5,6,7,8,16)$. Little is known about corynebacteria infection in nosocomial environment, especially in developing countries (18). In this work we were interested in determining the frequency of different species from clinical sources and the antimicrobial susceptibility profiles of corynebacteria isolated from patients of a teaching hospital in Rio de Janeiro, Brazil, using conventional identification methods.

\section{MATERIALS AND METHODS}

\section{Microorganisms and culture conditions}

The corynebacteria organisms studied were collected over a period of five years (September 1993 to December 1998), from patients hospitalized in different departments. The 163 strains were recovered from clinical specimens routinely submitted for culture in the microbiology laboratory of the Hospital Universitário Pedro Ernesto (HUPE/UERJ), a 600-bed teaching hospital, Rio de Janeiro, Brazil.

All specimens were cultured on Columbia agar supplemented with $5 \%$ sheep blood incubated at $37^{\circ} \mathrm{C}$ in a $3-5 \% \mathrm{CO}_{2}$ enriched atmosphere and inspected for $72 \mathrm{~h}$ incubation period. Blood samples were cultured with a continuous monitoring $\mathrm{CO}_{2}$ detection system (BACTEC 9240, Beckton Dickson and Company, Maryland, USA).

Coryneform organisms were selected for further identification if they were grown in any quantity from normally sterile body fluid or when they were recovered predominantly or in pure culture from other specimens. Corynebacteria were identified from urine cultures in Cystine Lactose Electrolytes Deficient agar (CLED-Merck, Darmstadt, Germany) when the colony count was $>10^{4} \mathrm{CFU} / \mathrm{ml}$ as the only isolate or at $>10^{5} \mathrm{CFU} / \mathrm{ml}$ as predominant isolate. A further selection of possibly infectionrelated isolates was based on clinical information obtained from the clinician treating the patient (e.g., fever, presence of catheters, administration of antibiotics, underlying disease) $(5,13,19)$.

\section{Characterization of microorganisms}

The strains were submitted to the Laboratório de Difteria e Corineformes de Importância Médica, DMI/FCM/UERJ for further characterization. The scheme used for identification of Corynebacterium sp. was based on biochemical tests used by different authors $(4,10,11,12,17)$ : morphology, pigmentation and hemolysis production of colonies, Gram stain morphology, catalase and nitrate reaction, motility, lipid requirement, urease, DNAse and pyrazinamidase (PYZ) production, esculin and gelatin hydrolysis, CAMP reaction and acid production from glucose, maltose, sucrose, xylose, mannose, fructose mannitol, trehalose, galactose and arabinose.

\section{Antimicrobial susceptibility assays}

Antimicrobial susceptibility was determined by using 5\% sheep blood in Mueller Hinton base and an inoculum of approximately $10^{5} \mathrm{CFU} / \mathrm{ml}$. The procedures for susceptibility testing, and the range of interpretative categories of susceptibility for each antimicrobial agent were similar to those recommended previously. Because of the absence of accepted breakpoints for coryneform bacteria to interpretative categories, those established for Kirby-Bauer disk diffusion method by the NCCLS for organisms other than Haemophilus species and Neisseria gonorrhoeae were used by the authors. The breakpoints for Staphylococcus aureus were considered in the cases of penicillin, oxacillin and ampicillin $(9,13,22,23)$.

\section{RESULTS AND DISCUSSION}

With the duration and intensity of immunossupression that patients are now subject to and the increased use of indwelling intravenous devices, the role of coryneform bacteria other than C. jeikeium became more significant than that of the past. Differences have been observed among Corynebacterium species most commonly recovered from human clinical materials 
by several authors $(13,19,20,23)$. Over a 14 -month period investigation, $C$. urealyticum, C. striatum, C. amycolatum and C. jeikeium predominated, accounting for $63 \%$ of 415 clinical isolates of coryneform Gram-positive rods recovered from various sources and identified to the species level according to recent identification schemes (19). Investigation of distribution of Corynebacterium species in instances where the source or quantity of organism suggested possible clinical significance demonstrated the predominance of certain species in different anatomic sites (Table 1). The most common species isolated from patients of a teaching hospital in Rio de Janeiro, Brazil were $C$. pseudodiphtheriticum (20.24\%), C. amycolatum (18.40\%), C. propinquum (17.17\%), C. minutissimum (12.26\%) followed by $C$. xerosis $(10.42 \%)$ and $C$. urealyticum $(5.52 \%)$. Five $C$. pseudodiphtheriticum, three C. minutissimum and four $C$. propinquum strains were isolated from clinical specimens of patients with AIDS. The most frequent sources were the genitourinary tract (26.99\%), surgical/skin wounds and abscesses (17.79\%), intravenous sites - catheters (10.42\%) and blood $(9.20 \%)$ followed by lower respiratory tract $(7.36 \%)$ specimens.

C. pseudodiphtheriticum strains were recovered predominantly from intravenous site (i.v.) $(18.18 \%)$ and genitourinary tract $(18.18 \%)$ followed by lower respiratory tract $(12.12 \%)$ and peritoneal fluids (12.12\%) specimens. Microorganisms were also isolated from skin sites $(9.09 \%)$ including surgical wounds. C. pseudodiphtheriticum and C. amycolatum predominated in genitourinary tract and blood specimens, accounting for $43.18 \%$ and $40.62 \%$ of all corynebacteria isolated from these materials, respectively.
The rate of recovery of C. amycolatum $(18.40 \%)$ was in accordance with previous studies (13\%) (9). In the present investigation, most of the strains $(43.33 \%)$ were isolated from genitourinary tract. C. amycolatum was the only species isolated from cerebral spinal fluid. C. amycolatum and C.xerosis were found predominantly $(70.58 \%)$ in materials obtained from catheter sites. C. xerosis was recovered from i.v. sites (25\%), skin wounds or abscesses $(10.34 \%)$, genitourinary tract or miscellaneous sites (7.23\%). C. xerosis occurred predominantly in materials obtained from catheter $(41.17 \%)$ sites but not from blood $(6.66 \%)$.

Previous studies demonstrated a high isolation rate (77\%) of C. minutissimum from blood or i.v. related cultures suggesting that these microorganisms may colonize catheters and cause bacteremia from this focus (23). The species C. accolens, $C$. striatum, $C$. argentoratense, $C$. propinquum and $C$. pseudodiphtheriticum but not C. minutissimum were isolated mainly from blood samples in other opportunity (19). In the present study C. minutissimum was not isolated from catheter sites; only one strain was isolated from blood samples. Results presented in Table 1 demonstrated that $C$. minutissimum strains were found mainly in genitourinary tract $(45 \%)$ and skin specimens including surgical wounds and abscesses (35\%).

Discrepancy among rates of recovery of species observed by different authors may be due to the difficulty in distinguishing C. amycolatum from C. xerosis, C. striatum and C. minutissimum using classical routine tests $(10,19)$.

C. propinquum had been previously recovered from human respiratory tract and blood specimens (11). In this Brazilian

Table 1. Number (\%) of nondiphtherial Corynebacterium species isolated from varied clinical specimens.

\begin{tabular}{|c|c|c|c|c|c|c|c|c|c|}
\hline \multirow{2}{*}{ Organism } & \multirow{2}{*}{$\begin{array}{l}\text { Number } \\
\text { of Isolates } \\
(\%)\end{array}$} & \multirow{2}{*}{$\begin{array}{c}\text { Urine/ } \\
\text { Urethral } \\
\text { Discharge }\end{array}$} & \multirow{2}{*}{$\begin{array}{c}\text { Surgical/ } \\
\text { Skin Wounds } \\
\text { and Abscess }\end{array}$} & \multicolumn{2}{|c|}{ Intravenous Sites } & \multirow{2}{*}{ LRT } & \multirow{2}{*}{$\begin{array}{l}\text { Peritoneal } \\
\text { Fluid }\end{array}$} & \multirow{2}{*}{ CSF } & \multirow{2}{*}{ Misc } \\
\hline & & & & Catheters & Blood & & & & \\
\hline C. pseudodiphtheriticum & $33(20.24)$ & $05^{\mathrm{R} /} 01$ & $01^{\mathrm{R} / 02}$ & $01^{\mathrm{R}}$ & 05 & $04^{\mathrm{HIV}+}$ & $04 \mathrm{HIV}+^{+}$ & 00 & $10^{\mathrm{R}}$ \\
\hline C. amycolatum & $30(18.40)$ & 13 & $01 / 03$ & 05 & 02 & 01 & 01 & 01 & 03 \\
\hline C. propinquum & $28(17.17)$ & 03 & $02 / 03$ & 01 & $04^{\mathrm{R}}$ & $04^{\mathrm{HIV}+}$ & 01 & 00 & 10 \\
\hline C. minutissimum & $20(12.26)$ & 09 & $04 / 03^{\mathrm{HIV}+}$ & 00 & 01 & 00 & 00 & 00 & 03 \\
\hline C.xerosis & $17(10.12)$ & 01 & $00 / 03$ & $07^{\mathrm{R}}$ & 01 & 00 & 00 & 00 & $05^{\mathrm{R}}$ \\
\hline C. urealyticum & $09 \quad(5.52)$ & 01 & $02 / 01$ & 00 & 00 & $01^{\mathrm{R}}$ & 00 & 00 & 04 \\
\hline C. striatum & $08 \quad(4.90)$ & $04^{\mathrm{R}}$ & $00 / 04$ & 00 & 00 & 00 & 00 & 00 & 00 \\
\hline C. afermentans & $06 \quad(3.68)$ & 03 & 00 & 00 & $01^{\mathrm{R}}$ & 01 & 00 & 00 & 01 \\
\hline C. pseudotuberculosis & $06 \quad(3.68)$ & 02 & 00 & 01 & 01 & 01 & 00 & 00 & 01 \\
\hline C. glutamicum & $04 \quad(2.45)$ & $01 / 01$ & 00 & 00 & 00 & 00 & 00 & 00 & 02 \\
\hline C. jeikeium & $01 \quad(0.63)$ & 00 & 00 & $01^{\mathrm{R}}$ & 00 & 00 & 00 & 00 & 00 \\
\hline C. glucuronolyticum & $01 \quad(0.63)$ & 00 & 00 & 01 & 00 & 00 & 00 & 00 & 00 \\
\hline Total (\%) & $163(100)$ & $44(26.99)$ & $29(17.79)$ & $17(10.42)$ & $15(9.20)$ & $12(7.36)$ & $06(3.68)$ & $01(0.61)$ & $39(23.92)$ \\
\hline
\end{tabular}

LRT, Lower respiratory tract; CSF, Cerebrospinalfluid; Misc, Miscellaneous sites (pure culture isolated from skin, superior respiratory tract or eye without clinical signs of infection); HIV+, at least one HIV patient isolate included; R, antimicrobial multiresistant isolates included. 
hospital, the species was frequently recovered from surgical wounds and abscesses, accounting for $17.24 \%$ of the skin isolates. C. propinquum was also isolated from blood and catheter specimens, $26.66 \%$ and $5.88 \%$, respectively. $C$. propinquum and C. pseudodiphtheriticum constituted $66.66 \%$ of all corynebacteria isolated from the respiratory tract.

A high isolation rate of $C$. jeikeium and C. urealyticum should be expected since both species have been long recognized to colonize or infect the hospitalized and/or compromised host in industrialized countries (11). However, during the period of the present study, only one C. jeikeium strain was isolated from catheter site. Four of the $C$. urealyticum isolates seemed to represent colonization other than infection among hospitalized patients; five strains were obtained from surgical wounds or abscesses, genitourinary and lower respiratory tract specimens.

During the last two decades a renewed interest in Corynebacterium species has come out among clinicians and microbiologists. Infections caused by these organisms are emerging, new species are been recognized, and infections by toxigenic and nontoxigenic $C$. diphtheriae strains are also being described with increasing frequency, indeed, in countries were diphtheria have been totally or almost eradicated $(16,17,18)$. However, this renewed interest has not been followed by an in depth study to determine the antimicrobial susceptibility of such organisms. Most available data come from scattered case reports, studies on a particular organism, or very old reports (22). Most recent studies show an alarming rate of antibiotic resistance among Corynebacterium species and other facultative, non-spore-forming, Gram-positive bacilli. Resistance to $\beta$-lactams, clindamycin, erythromycin, azythromycin, ciprofloxacin, and gentamicin is quite frequent, with vancomycin, doxycycline, fusidic acid, and prystinamycin being the agents that are most active in vitro (15). Antimicrobial susceptibility tests may be of utility when prescribing antibiotics in cases in which any of the present organisms are involved in clinical infections. Resistance to many antibiotics is increasing, and so determination of their susceptibilities may be necessary in order to obtain the best therapeutic results. The ultimate therapeutic regimen must be chosen according to the in vitro results, the location of the infection, and previous clinical experience $(13,19,21,22)$.

Table 2 summarizes the antimicrobial susceptibility results presented by Corynebacterium strains found in nosocomial environment in Rio de Janeiro, Brazil. Most strains were resistant to penicillin, oxacillin, ampicillin, ceftazidime, lincomycin and chloranphenicol. C. jeikeium and C. xerosis isolates were the most resistant organisms tested. Vancomycin, cefuroxime, cefoxitin and ceftriaxone showed higher activity in vitro against the different corynebacteria species. The spectrum of activity to most antimicrobial agents was variable suggesting their limited therapeutic potential.

Penicillin and oxacillin were the least active antibiotics against the clinical strains during the in vitro assays. A particular concern is the increasing number of penicillin-resistant corynebacteria strains initially observed among $C$. xerosis, $C$. minutissimum and C. striatum (22). Present data suggest that penicillin-resistant strains also appear among C. afermentans, C. pseudotuberculosis, C. pseudodiphtheriticum, C. propinquum and C. amycolatum. Of interest were the different activities of the cephalosporins (ceftazidime, cefotaxime, cephalotin, ceftriaxone, cefoxitine, and cefuroxime) to these microorganisms. The isolates showed higher susceptibility to cefuroxime, cefoxitin, ceftriaxone, and cephalotin. Strains of

Table 2. Antimicrobial susceptibility of Corynebacterium sp. strains.

\begin{tabular}{|c|c|c|c|c|c|c|c|c|c|c|c|c|c|c|c|c|c|c|}
\hline \multirow[b]{2}{*}{ Organism } & \multicolumn{18}{|c|}{ Percentage of Susceptible Strains } \\
\hline & PEN & OXA & AMP & CAZ & LIN & CHL & STX & GEN & TET & PEF & ERY & CTX & AMK & $\mathrm{CEF}$ & $\mathrm{CRO}$ & FOX & CXM & VAN \\
\hline C. jeikeium & $\mathbf{0}$ & $\mathbf{0}$ & $\mathbf{0}$ & $\mathbf{0}$ & $\mathbf{0}$ & $\mathbf{0}$ & $\mathbf{0}$ & $\mathbf{0}$ & $\mathbf{0}$ & $\mathbf{0}$ & $\mathbf{0}$ & $\mathbf{0}$ & $\mathbf{0}$ & $\mathbf{0}$ & $\mathbf{0}$ & $\mathbf{0}$ & $\mathbf{0}$ & 100 \\
\hline C. xerosis & 13 & 13 & 25 & 13 & 38 & 38 & 25 & 38 & 25 & 38 & 50 & 50 & 63 & 38 & 50 & 50 & 50 & 100 \\
\hline C. afermentans & $\mathbf{0}$ & $\mathbf{0}$ & 33 & 33 & $\mathbf{0}$ & 67 & 33 & 67 & 100 & 67 & 67 & 33 & 33 & 67 & 67 & 67 & 67 & 100 \\
\hline C. pseudotuberculosis & $\mathbf{0}$ & 50 & $\mathbf{0}$ & 50 & 75 & 50 & 25 & 50 & 75 & 100 & 75 & 100 & 100 & 100 & 100 & 100 & 100 & 100 \\
\hline C. striatum & 67 & 67 & 67 & $\mathbf{0}$ & 33 & $\mathbf{0}$ & 67 & 33 & 67 & 67 & 33 & 67 & 67 & 67 & 67 & 67 & 67 & 100 \\
\hline C. minutissimum & 22 & 11 & 78 & 22 & $\mathbf{0}$ & 44 & 55 & 55 & 78 & 78 & 55 & 89 & 67 & 67 & 67 & 78 & 89 & 100 \\
\hline C.pseudodiphtheriticum & 42 & 26 & 47 & 37 & 32 & 58 & 53 & 63 & 53 & 53 & 53 & 68 & 68 & 63 & 68 & 58 & 58 & 100 \\
\hline C. propinquum & 22 & 22 & 55 & 55 & 22 & 55 & 22 & 55 & 44 & 67 & 55 & 67 & 55 & 55 & 67 & 67 & 67 & 100 \\
\hline C. amycolatum & 35 & 40 & 55 & 45 & 65 & 40 & 55 & 80 & 85 & 80 & 80 & 95 & 80 & 85 & 95 & 95 & 90 & 100 \\
\hline C. glutamicum & 100 & 100 & 100 & 100 & 100 & 100 & $\mathbf{0}$ & 100 & 100 & $\mathbf{0}$ & 100 & 100 & 100 & 100 & 100 & 100 & 100 & 100 \\
\hline C. glucuronolyticum & 100 & 100 & 100 & 100 & 100 & 100 & 100 & 100 & 100 & 100 & 100 & 100 & 100 & 100 & 100 & 100 & 100 & 100 \\
\hline
\end{tabular}

PEN, penicillin G; OXA, oxacillin; AMP, ampicillin; CAZ, ceftazidime; LIN, lincomycin; CHL, chloranphenicol; STX, Trimethoprimsulfamethoxazole; GEN, gentamicin; TET, tetracycline; PEF, pefloxacin; ERY, erythromycin; CTX, cefotaxime; AMK, amikacin; CEF, cephalotin; CRO, ceftriaxone; FOX, cefoxitin; CXM, cefuroxime; VAN, vancomycin. 
different species showed resistance to ceftazidime and dissociated susceptibility to cephalotin and cefuroxime as observed in previous studies with Listeria monocytogenes (14). Only C. glutamicum and C. glucuronolyticum strains were susceptible to the $\beta$-lactams.

Gentamicin was active against most isolates, although resistance was mainly common in C. striatum, C. xerosis and C. pseudotuberculosis.

Lincosamides and macrolides have been considered good therapeutic alternatives, but numerous resistant strains have now appeared among many organisms. Resistance to erythromycin was observed in C. pseudodiphtheriticum, C.xerosis, C. striatum and $C$. minutissimum (22). In our work, lincomycin was less active than erythromycin and tetracycline. Erythromycin-resistant strains also appeared among nosocomial isolates of $C$. afermentans, $C$. pseudotuberculosis, C. propinquum and C. amycolatum besides C. pseudodiphtheriticum, C. xerosis, C. striatum and C. minutissimum.

Multiple antibiotic resistance was observed not only in $C$. jeikeium but also among C.xerosis, C. minutissimum, C. afermentans, C. propinquum, C. amycolatum and C. pseudodiphtheriticum strains.

Our assessment of corynebacteria isolates showed that several Corynebacterium species exhibiting unpredictable antimicrobial susceptibility patterns might be encountered in Brazilian hospital environment. Therefore, additional efforts for accurate identification at the species level of coryneform nosocomial pathogens and continuous surveillance of their resistance patterns are required.

\section{ACKNOWLEDGMENTS}

This work was supported by grant from CNPq, CAPES, FAPERJ, SR-2/UERJ and Programa de Núcleo de Excelência (PRONEX) of the Brazilian Ministry of Science and Technology.

\section{RESUMO}

\section{Corynebacterium spp. isoladas a partir de espécimes clínicos de pacientes de Hospital Universitário, Rio de Janeiro, Brasil}

Durante um período de cinco anos, foram isoladas 163 amostras de Corynebacterium sp. a partir de espécimes clínicos obtidos de pacientes de um Hospital Universitário brasileiro. Os microrganismos foram predominantemente observados (46.62\%) em materiais oriundos de sítios intravenosos e trato geniturinário. Amostras de Corynebacterium amycolatum (29.55\%), Corynebacterium minutissimum (20.45\%) e Corynebacterium pseudodiphtheriticum (13.63\%) foram predominantemente isoladas do trato geniturinário; $C$. minutissimum (24.14\%) e Corynebacterium propinquum (17.24\%) de feridas cirúrgicas e/ou outras lesões cutâneas e abscessos; Corynebacterium xerosis $(25 \%)$, C. amycolatum (21.87\%) e C. pseudodiphtheriticum (18.75\%) de sítios intravenosos; C. pseudodiphtheriticum $(33.33 \%)$ e $C$. propinquum $(33.33 \%)$ do trato respiratório inferior. A maioria das espécies exibiu resistência a antimicrobianos do grupo dos $\beta$-lactâmicos e todas as amostras foram vancomicina-sensíveis. Dentre as espécies de corinebactérias isoladas, as amostras exibiram perfis heterogêneos de susceptibilidade aos antimicrobianos. Além de $C$. jeikeium, a multirresistência aos antimicrobianos também foi observada em amostras de $C$. xerosis, C. minutissimum, C. afermentans, $C$. propinquum, $C$. amycolatum e C. pseudodiphtheriticum. Os dados enfatizam a necessidade de clínicos e microbiologistas permanecerem atentos à possibilidade de processos infecciosos nosocomiais serem ocasionados por Corynebacterium sp., particularmente por amostras multiresistentes aos antimicrobianos.

Palavras-chave: Corynebacterium sp, corinebactérias, infecção nosocomial, multiresistência.

\section{REFERENCES}

1. Assis, T.L.; Formiga, L.C.D.; Filgueira, A.L. "Pé de atleta" subsídios conceituais. An. Bras. Dermatol., 60: 333-336, 1985.

2. Collins, M.D.; Bernard, K.A.; Hutson, R.A.; Sjöden, B.; Nyberg, A.; Falsen, E. Corynebacterium sundsvallense sp.nov., from human clinical specimens. Int. J. Syst. Bacteriol., 49: 361-366, 1999.

3. Coyle, M.B.; Lipsky, B.A. Coryneform bacteria in infections diseases: clinical and laboratory aspects. Clin. Microbiol. Rev., 3 (Suppl.3): 227-246, 1990.

4. Formiga, L.C.D. Isolamento e caracterização de bastonetes gram positivos referidos como "difteróides". Tese de mestrado apresentada no Instituto de Microbiologia da UFRJ. 1974. 86p.

5. Formiga, L.C.D.; Camello, T.C.F. Quando, porque e como devemos identificar os corineformes. Rev. Bras. Patol. Clin., 23: 116-118, 1987.

6. Formiga, L.C.D.; Malbourg, T.C.M.; Silva, C.A.M.; Suassuna I. Estudo do agente etiológico do eritrasma. II - Reações sorológicas com o gênero Corynebacterium. Rev. Microbiol. São Paulo, 24: 62-64, 1988.

7. Formiga, L.C.D.; Mattos-Guaraldi, A.L. Diphtheria: current status and laboratory procedures for diagnosis. Rev. Bras. Patol. Clin., 29: 93-96, 1993.

8. Formiga, L.C.D.; Vieira, L.M.M.; Assis, T.L.; Suassuna I. Estudo do agente etiológico do eritrasma. I- Características dos difteróides fluorescentes. Rev. Microbiol. São Paulo, 14: 97-105, 1983.

9. Funke, G.; Punter, V.; von Graevenitz, A. Antimicrobial susceptibility patterns of some recently established coryneform bacteria. Antimicrob. Agents Chemother., 40: 2874-2878, 1996.

10. Funke, G.; Bernard, K.A. Coryneform Gram-Positive Rods. In Murray, P.R.; Baron E.J.; Pfaller, M.A. Tenover, C.; Yolken, R.H. (eds). Manual of Clinical Microbiology, $7^{\text {th }}$ ed. ASM Press. Washington, D.C, 1999, p: 319-345.

11. Janda, W.M. Corynebacterium species and the coryneform bacteria Part I: New and emerging species in the genus Corynebacterium. Clin. Microbiol. Newslett., 20: 41-52, 1998.

12. Janda, W.M. The corynebacteria revisited: new species, identification kits, and antimicrobial susceptibility testing. Clin. Microbiol. Newslett., 21: 175-182, 1999. 
13. Lagrou, K.; Verhaegen, J.; Janssens, M.; Wauters, G.; Verbist, L. Prospective study of catalase-positive coryneform organisms in clinical specimens: identification, clinical relevance and antibiotic susceptibility. Diag. Microbiol. Infect. Dis., 30: 7-15, 1998.

14. Mac Gowan, A.P.; Holt H.A.; Bywater M.J.; Reeves D.S. In vitro antimicrobial susceptibility of Listeria monocytogenes isolated in the UK and other Listeria species. Eur. J. Clin. Microbiol. Infect. Dis., 9: 767-770, 1990.

15. Martinez-Martinez, L.; Suarez, A.I.; Ortega, M.C.; Perea, E.J. Comparative in vitro activities of new quinolones against coryneform bacteria. Antimicrob. Agents Chemother, 38: 1439-1441, 1994.

16. Mattos-Guaraldi, A.L.; Formiga, L.C.D. Corynebacterium diphtheriae and diphtheroids: adhesive properties. Rev. Bras. Patol. Clin., 27: 53-59, 1991

17. Mattos-Guaraldi, A.L.; Formiga, L.C.D. Bacteriological properties of a sucrose-fermenting Corynebacterium diphtheriae strain isolated from a case of endocarditis. Curr. Microbiol., 37: 1-4, 1998.

18. Mattos-Guaraldi, A.L.; Formiga, L.C.D.; Camello, T.C.F.; Pereira, G.A.; Hirata Jr, R.; Dias, L.M.D.; Halpern, M. Corynebacterium diphtheriae threats in cancer patients. Rev. Argentina Microbiol., 33: 96-100, 2001.
19. Riegel, P.; Ruimy, R.; Christen, R.; Monteil, H. Species identities and antimicrobial susceptibilities of Corynebacteria isolated from various clinical sources. Eur. J. Clin. Microbiol. Infect. Dis., 15: 657-662, 1996.

20. Sjöden, B.; Funke, G.; Izquierdo, A.; Akervall, E.; Collins, M.D. Description of some coryneform bacteria isolated from human clinical specimens as Corynebacterium falsenii sp. Int. J. Syst. Bacteriol., 48: 69-74, 1998.

21. Soriano, F.; Fernadez-Roblas, R.; Calvo,R.; Garcia-Calvo G. In vitro susceptibilities of aerobic and facultative non-spore-forming gram positive bacilli to HMR 3647 (RU66647) and 14 other antimicrobial agents. Antimicrob. Agents Chemother., 42: 10281033, 1998.

22. Soriano, F.; Zapardiel, J.; Nieto, E. Antimicrobial susceptibilities of Corynebacterium species and other non-spore-forming gram positive bacilli to 18 antimicrobial agents. Antimicrob. Agents Chemother., 39: 208-214, 1995.

23. Williams, D.Y.; Selepak, S.T.; Gill, V.J. Identification of clinical isolates of nondiphtherial Corynebacterium species and their antibiotic susceptibility patterns. Diag. Microbiol. Infect. Dis., 17: 23-28, 1993. 